 \\ Research Article \\ (c) 2021 Hyginus Obinna Ogbonna. \\ This is an open access article licensed under the Creative Commons \\ Attribution-NonCommercial 4.o International License \\ (https://creativecommons.org/licenses/by-nc/4.0/)
}

Received: 29 May 2021 / Accepted: 30 June 2021 / Published: 8 July 2021

\title{
A Monograph on Theoretical Understanding of the Contradictions of Vested Interests and Underdevelopment in Peripheral Social Formation
}

\author{
Hyginus Obinna Ogbonna
}

\author{
Department of Sociology and Anthropology, \\ Faculty of Social Sciences, University of Benin, Nigeria
}

DOI: https://doi.org/10.36941/mjss-2021-0o34

\section{Abstract}

This paper focuses on theoretical understanding of the contradictions of vested interests and the underdevelopment in the peripheral social formations; having as its raison d'être, to explore the possible ways by which the vested interests of a particular social group or class has contributed in shaping the underdevelopment of the periphery in the global economy-with inferences from a sub-Saharan African country, Nigeria (with empirical-based evidences); and moving forward, to find ways to counteract or mitigate these contradictions for the amelioration of the human condition in the periphery. Thus, the paper achieves its objectives by adopting a qualitative descriptive method of analysis, investigating the contradictions of the vested interests of both the neo-colonial elite in the Periphery and the capitalists of the Center (advanced capitalist nations), with an admixture of "Dependency Perspective" in its exploration. A theoretical framework, Marxian Ideology, was employed to help for a better epistemic understanding of the dynamics of vested interests aided by helpful extrapolations in its analysis. In the final analysis, the paper made some findings. A few of these include, 1) that the ruling class of the peripheral nations, especially in Africa (typically, Nigeria) has the culture of diverting national wealth for own personal interest. 2) That every moment of domination precipitates moments of resistance by the subjugated class, hence revolutions and instability are endemic in any polity fraught with vested interests of the dominant class. 3) That the peripheral nations have remained underdeveloped due to the selfish interests of both the peripheral ruling class (the puppets of the capitalist of the Center) and the advanced capitalist nations. The paper therefore recommends: that the peripheral social formations should pursue serious independent policies of social justice along egalitarian lines as well as economic and political self-reliance -e.g. state incentives for local industrialists and integrating and strengthening the domestic productive base to attain a self-reliant articulated economy. 2) There is need for total commitment to democratic ethos or permissiveness including popular-empowerment in every aspect for the amelioration of the human condition; among others.

Keywords: Periphery, Peripheral Social formation, Social formation, Underdevelopment, Vested Interests

\section{Introduction}

The modern world comprises a single capitalist world-economy which has emerged historically since the 16th century and still exist today. It follows from such a premise that national states are not societies that have separate,parallel histories but parts of a whole reflecting that whole. But to understand the internal class contradictions and political struggles of a particular state, we must first situate it in the world-economy. - Wallerstein (1979). 
Corpus of literature in the past have attempted to investigate the factors leading to the underdevelopment of the less developed countries (LDC's) vis-à-vis the development of the more developed countries (MDC's). Thesis and insights that may accrue from this plethora of literature tend to tilt towards the popular proposition -especially, that of the neo-Marxist Dependency ideology -- that the western advanced capitalist powers are the culprits as regards the underdevelopment of the peripheral countries (Gunder, 1966; Wallerstein, 1979 and Amin, 1974).

Admittedly, to a limited or greater extent, the modern world comprises a single capitalist worldeconomy which has emerged historically since the 16th century and which still exists today. It therefore follows that national states (especially, the peripheral states) are not societies that have separate histories but parts of the whole reflecting that whole (ala Wallerstein, 1979). That is to say, the peripheral social formations as part of this whole must, inevitably, be influenced by this capitalist world-economy which as a consequence has led to the "development of the rich advanced nations (the Center) and the underdevelopment of the poor ones" (the Periphery). Agreed! But our faithful observers in this persuasion have conspicuously ignored one thing: that, in as much as the unequal relations between the less developed countries and the more developed advanced capitalist nations has led to the underdevelopment of the former; the socio-politico-economic structural distortions and ruptures arising from the vested interests of the neo-colonial elites (the ruling class) within the local economy of the periphery which tends to accentuate and even perpetuate the very interest of the "bourgeoisie of the Center" (the advanced capitalist nations), is in all intents and purposes contributory! Typically, the history of Nigeria since Independence epitomizes the manifestations of these socio-political and economic structural contradictions within the periphery. As Ninalowo (2004:86) noted, "the so called development strategies over the years have been quantitatively oriented and more in the favour of dominant actors within the peripheral neo-colonialist states to the detriment of the subaltern classes (the civil society: peasants and urban workers, the poor masses)" the oil boom era of Shagari (1979 - 1983) yet the standard of living of the masses was very low, cannot be quickly forgotten. In 2006, the economic growth rate of Nigeria was claimed to be as high as $6.2 \%$ (Adepolu, 2011:11), yet the human condition of the masses worsen with high rate of unemployment, and mortality rates at high level of 97 per 1000 (Financial Standard, January 29, 2007). By 2020 the socioeconomic condition within the nation was even worse with poverty rate as high as $40 \%$ (NBS, 2020), unemployment rate as high as $23 \%$ (Premium Times January $19^{\text {th }}$, 2020); Nigeria ranked the world's third lowest with low life expectancy rate of 55 years in 2020 (Premium Times January $19^{\text {th }}$, 2020) -while the political elites (the ruling class) are busy carting away billions into their private accounts to the detriment of the generality of the populace. Hence, while we project the anomalies of the vested interests of advanced capitalists nations in the world economy, we shall not be parochial and play the Ostrich, and slam our blinders over the socio-politico-economic structural contradictions of 'class interest' (the ruling class interests) and antagonisms within the peripheral economy which is also a fall-out of the patterns of skewed economic relationship between the Core and the Periphery. To be sure, that will, to a greater extent provide an insightful (if not total) perspective that grasps the essence of the root of the contradictions of the underdevelopment of the peripheral social formations impinged on vested interests.

Therefore, to accomplish the expectations of the raison d'etre of this essay, the task before us here, is to explore some of the possible ways by which the contradictions of vested interests -both within the peripheral local economy of the state (with regard to neo-colonial elite of the state) as one aspect; and the vested interests of the 'bourgeoisie of the Center' (advanced capitalist nations) as another aspect -are interlinked with the underdevelopment of the peripheral social formations. The corpus of the gleanings accruing from this exploration shall be rounded up with some propositions of recommendations. It is hoped that these would provoke quest for further inquiries. We shall return shortly to these in the furtherance of the discourse. 


\section{Objectives of the Study}

The general objective of the paper is to explore the possible ways by which vested interests of a particular social group (the capitalist advanced nations, and the local neo-capitalist of the peripheral nations) are contributory to the underdevelopment of the peripheral social formations; and specifically, to identify ways to mitigate this anomaly for the amelioration of the human condition in the peripheral states of the Global South.

\section{Conceptual Clarifications}

Under this rubric, the ways by which certain concepts have been used shall be clarified to help an insightful understanding. To this we now turn.

\subsection{Vested Interests}

The phrase suggests a special interest in protecting or promoting that which is to one's own personal advantage. David Hume (1948) termed it as, 'selfishness and limited generosity'. Ninalowo (2004) sees it as, 'class-oriented interests'. However, at the risk of over-simplification, the following nomenclatures are posited as synonyms: class interests; vested individual interest; private individual economic interest; or human self-interest. And for our epistemic purpose here, we pin it down as 'the interests of the dominant class as opposed to general interest'.

\subsection{Underdevelopment}

It is a process by which less developed societies, the Global South countries (incorporated into the capitalist world-economy) have low technology, low or weak structural institutions, and low economic and human development vis-à-vis other highly technological and economic advanced societies. Its characteristics include, low income per capita, low standard of living, high mortality rate/poor access to health facilities, high rates of unemployment, significant dependence on unmechanized agriculture, low literacy rate and total dependence and vulnerability in the international economic relations.

\subsection{Periphery}

This refers to an economy where major, and even minor, economic institutions are dominated by transnational corporations and their local agents (Wallerstein, 1979 and Ninalowo, 2004). To be sure, the socio-political even the cultural spheres of such economy are also influenced by these dominant forces. That is to say, the term refers to the less developed countries (the satellite) whose economies are overtly or covertly dominated by these technologically advanced capitalist nations. Its obverse is the 'Core' (the 'Center') represented by the advanced capitalist nations in the world economy. The Periphery is unmistakably, the 'wretched of the earth' (Fanon. 1963) vis-à-vis the Core!

\subsection{Social Formation.}

It refers to the organization of society characterized by a dominant mode of production, say feudalism, capitalism or socialism (Wilmot, 1985:93). Hence, one can, for instance, aptly inter-change the term 'capitalist mode of production' with 'capitalist social formation'. Thus, at this juncture, it becomes easier to demystify the term, 'Peripheral Social Formation'. 


\subsection{Peripheral Social Formation}

Drawing helpful insights from the above conceptualization of social formation, one may paraphrase 'peripheral social formation' as the 'peripheral mode of production'. That is, the type of economic mode or system within the less developed dependent nations in the world economy. As a matter of specification, Ninalowo (2004: 161) narrowed it down to, "the newly emerging nation-states of Africa". Newly emerging, because most of them have just gained 'nominal-flag-political independence' - a ceremonial sort of independence while still economically dependent on the advanced capitalist nations. Thus, in this discourse, we shall interchange peripheral social formations with 'peripheral states'.

\section{Literature review}

As was promised ab initio, we shall now proceed to explore the possible ways by which the contradictions of vested interests both by the neo-colonial elites within the political economy of the periphery and that of the vested interests of the bourgeoisie of the 'Center' (advanced capitalist nations) are inter-linked with the underdevelopment of the periphery. We shall examine these, in sequence.

4.1 The Vested Interests of the Neo-colonial Peripheral Elites versus the Contradictions of Underdevelopment of the Periphery

One of the most insidious characteristics of dependent development has to be the unequal distribution of economic benefits in peripheral social formations: Accumulation of capital is confined to a select group of economic and political elites; namely, transnational and their local agents -state and 'private' functionaries in peripheral political economies.- Ninalowo (2004: 109).

As was earlier adumbrated, the peripheral social formation is an economy where major and minor economic institutions are dominated and exploited by transnational corporations and their local lackeys (Ninalowo, 2004). To be sure, such economy has its socio-political and cultural spheres influenced to some extent by these economic forces. However, our focus under this rubric is to identify some of the key organs or apparatuses of the peripheral social formation and how they are interlinked with each other. It is hoped that the linkages of the various organs in terms of the ways in which the vested interests of the political elites (the ruling class) maintain and perpetuate structural inequalities and its contradictions of the underdevelopment of the periphery would be unveiled. We shall now turn to some of these key organs, in what follows.

\subsection{The Government}

The neo-colonial bourgeoisie (the ruling class at the periphery) true to its calling remains physically, socially, and psychologically closer to its masters in Europe than to the denizens of the hinterland. Wilmot (1985: 163).

For the epistemic purpose of this monograph, government here refers to the executives of the modern state -the 'class state' or the ruling class (although, by its legitimate establishment not expected to metamorphous into a 'class state': the political class becomes 'a class state' where it is for its own vested interests). Ideal-typically, the state qua state; that is, the state in its legitimate purpose for being, is to provide facilities for the amelioration of the human condition -human centered development facilities like, education, water, housing, health care delivery, and good living standard for the people. But in contradistinction, the state, rather the 'class state', has become dominant vehicle by which the ruling class reinforces and reproduces its domination over the subordinate 
classes of the citizenry by managing the public resources for their own interests rather than for the generality of the citizens. Without doubt, Mark and Engels (1969: 110-111) highlighted the dynamics of this structural class relation with their seasoned and insightful utterances when they affirmed that, "the executive of the modern state is but a committee for managing the common affairs of the whole bourgeoisie". As an ancillary to that, Arthur Nwankwo (1989: 23, 24) a political scientist and a social critic presented it more directly, albeit in a deserving blunt taste:

\begin{abstract}
"Nigerian leaders show that they make history merely by consolidating themselves and their species as the executive committee of an indigenous class of predators lodged in neo-colonialism...Indigenous political buffoons manage the state apparatus on behalf of their expatriate mentors who controlled local productive forces; this alien ruling class [the bourgeoisie of the Center] monopolize the secrets of science and technology while indigenous elites [bourgeoisie of the Periphery] remain contented with the role of puppet partners because their major motive in the political affairs is to preserve the status quo...The alliance between the foreign financiers and their local accomplices has woven Nigeria more and more into the metropolitan centres of international capital. The political and socio-cultural dialectics of this economic phenomenon has amounted to a re-colonization of the Nigerian political system".
\end{abstract}

Thus, the government instead of being the government for the general interest of the public has rather metamorphosed into 'government for the ruling class' (a 'class state') - in my opinion, and without mincing words, it becomes a government reducible to: 'government of them-them, by themthem, and for them-them'. In concrete terms, within the geo-political clime of the advanced nations, the political philosophy of the bourgeoisie of the advanced capitalist nations is 'permanent national interest'; but for the bourgeoisie of the peripheral nations, on the contrary, the political philosophy is rather 'apopular' - non-populist oriented: the hidden political philosophy is 'permanent interests of the ruling class'; and in order to sow a seed of 'false consciousness' in the subject class (the poor masses), they seek legitimacy in their 'apopular' hoax to silence and repress the prying eyes of the people by making their vested interests to appear as the interest of the generality of the people. For in any dialectical relations to production of class cleavages, the ruling class in their surreptitious and deceptive bourgeoisie rationality usually has the tendency to trick the subject class into believing that 'what is good for the ruling class is equally good for the people (the subject class: the poor masses). And worse still, this ruling class (rather 'class state') has the collective interest in maintaining the neo-colonial capitalist basic order, and securing it against any challenge from below (William, 1982) and in securing the status quo, they usually apply repressive measures at all cost against any forms of resistance from the civil society: a typical scenario is the 'End-SARS' protests by the civil society (irate youths, the marginalized and the socially excluded) in Nigeria in October 2020 -during the administration of president Buhari -who protested against police brutality and the worsening socioeconomic conditions in Nigeria, only for the government to send soldiers to dislodge the peaceful protest at Lekki Toll gate Lagos, shooting the unarmed protesters in the imbroglio, and many lost their lives. The aim is usually to maintain the capitalist stranglehold; and the path to development in the peripheral state stifled in the process. Indeed, the Nigerian state apparatus hijacked by the vested interests of the ruling class merited the metaphorical descriptive literary articulation ('Ambush') of Gbemisola Adeoti in one of his poetic lines, "the land [the Nigerian state] is a sabre-toothed Tiger [oppressive ruling class] that cries deep in the glade while infants [the subject class] shudder home...from bayonets of tribulation...The land is a giant whale [the overbearing dominant class] that swallows the sinker, with hook [efforts of the subject class] aborting the dreams of a good catch, fishers [the poor masses] turn home at dusk on empty ships"! By the same token, Arthur Nwankwo (1989 : v-vi), writing with adroit precision, captured this insalubrious repressive tactics of the ruling class interests geared against resistance, vividly: "fascistic African regimes not only rely on crude violence for the elimination of dissident social forces, they use mass starvation as an instrument of murder...The despotic mannerisms of African leadership and their congenital penchant for using the state [here, political power or office] as a merchant of death tend to reinforce 
the Hermitic prejudice against Africa as a continent of barbarians”. In similar vein, Donald Trump (former President of U.S.A, 2016-2020) in the light of African poor leadership referred Africa and its leadership as 'shit-holes'. But are we "shit-holes"? -it appears we are acting true to type!

Although, our trickle-down development theorists have often pontificated that, what is good for the political elites is equally good for the society as a whole because its dividends will trickle down to the rest of the people. Such aphorism is questionable as it has a hidden dialectical conflict between dominant class interests with the national interest. We shall buttress this with salient empiricalbased examples from Nigeria's political landscape in what follows.

It is now a common knowledge that looting of the public treasury, kickbacks both in local and foreign currencies in billions and money laundering (several Governors have been indicted); awards of government contracts and 'over-invoicing' (Ette-gate saga: 'Madam Speaker', a case in point); selling of public corporations by the ruling class in collusion with transnational agents, have been rampant within Nigeria's socio-political milieu. The pathetic corrupt practices and/or graft in the psyche of the Nigerian political class have further graduated into pitiable laughable epic heights to include animal species: it is only in Nigeria that Snakes (reptile specie) and Monkeys (apes specie) are purported by the political class to swallow money. This is neither far-fetched nor a fable: during the first tenure of president Buhari's administration (2015-2019), it was alleged that snakes swallowed N37 million at the JAMB vault (Vanguard February $17^{\text {th }}, 2018$ ), while another older specie of the animal kingdom, the Monkeys swallowed N70 million belonging to the Northern Senators Forum (NSF) under the watch of Senator Adamu (who was then being dismissed as the NSF national chairman) who claimed that the missing $\mathrm{N}_{70}$ million was swallowed by Monkeys in his farm (Vanguard February 21, 2018) -This was amidst the rising incidence of poverty in the nation, especially in the Northern part of Nigeria as the World Bank (2020) reported that $87 \%$ of poor people in Nigeria are from the North. More so, more than 82 million Nigerians live below the poverty line of less than $\$ 1$ per day (NBS, 2020) with urban poverty index rated at $18.04 \%$, and rural poverty index estimated at $52.10 \%$ (NBS, 2020). Additional empirically based data shall be constructive here to further demonstrate the contradictions of the vested interests of the ruling class in Nigerian political landscape: during the administration of the former military President, Major General Ibrahim Babangida (retrd), Nigeria earned a huge sum of money to the tune of $\$ 12.4$ billion USD (Daily Independent July 31, 2010) in oil exports during the Gulf war (Iraq-Kuwait war) of 1991 in what was tagged to be an "oil wind fall" that brought the international oil price to unprecedented levels; and yet such revenue never reflected on the welfare of the Nigerian citizens as the human development index for Nigeria in 1990/91 was abysmally low at 0.242 index (UNDP, 1991), thus ranking 129 out of 160 countries reviewed in 1991 (UNDP, 1991). Poverty levels at the same year was $42.7 \%$ (NBS, 2003) increasing to $65.6 \%$ by 1996 (NBS, 2003), 5 years after the so called "oil wind fall" -signifying that the oil gains from the 1991 "oil wind fall" never reflected on the wellbeing of Nigerians but was hijacked by the vested interests of the ruling class. Again, during the present President Buhari's administration, his government in the revised 2020 national budget review slashed the budget of critical sectors of the economy, education and health sectors -the social protection sectors -with education sector slashed down by $54 \%$ from its initial figure of N111.78 billion to $N_{51.1}$ billion, health sector reduced by $42 \%$ from its initial figure of $\mathrm{N}_{44.49}$ billion to $\mathrm{N} 25.5$ billion (amidst the deadly COVID-19 pandemic that should have been a rationale for an increased budget for the sector), while allocating the National Assembly (the parliamentarians') expenditure a whopping sum of N115.2 billion, plus additional N27 billion for National Assembly complex renovation (Punch June 3, 2020). Pitiably, renovation of Law-makers building (N27 billion) was valued more than the critical health of the citizens (budgeted at paltry sum of N25 billion); parliamentarians' affairs (N115.2 billion) valued more than the citizens' access to education (budgeted at $\mathrm{N}_{51.1}$ billion). This vividly underscores where the interests of the political class lies -vested class interests at the expense of the general interest of the poor masses!

Thus, this "lootomania" and graft practices of the ruling class for own interests further depletes the remnants of resources left over by the imperialist thereby stifling development in the periphery. 
Interestingly, Wilmot (1985) was right when he observed that, "the leadership of many Third World countries (the peripheral nations) is extremely "religious". But the god of this religion is money; its worship is looting; its sacraments, booty; its earthly reward, plunder. About the only thing that the neo-colonial elite can agree upon is the right to steal!" (p. 190). This moral decadence among the ruling class is "inimical to the welfare of the masses, they are actually anti-development" (Ninalowo, 2004: 90).

\subsection{Politics}

Under this rubric, we shall explore how the political behavior and motives of those who seek 'political power' in the peripheral societies, due to the contradictions of their vested interests, translate into underdevelopment of the periphery.

Usually, in advanced capitalist nations of the Global North, those who seek 'political power' are wealthy individuals already wielding 'economic power'; who as it were, hope to use their economic clout to better the human condition of their people; contrariwise, in the peripheral nations of the Global South, those who seek 'political power' are persons with humble economic background who seek to use the 'political power' as a means to gain 'economic power' so as to, first, better their own poor conditions and their families and cronies before catering for the interest of the entire citizenry. Typically, Miliband (1977: 108-9) captured this contorted 'political power' scenario in the periphery with concrete precision: "In such cases, the relation between economic and political power has been inverted: it is not economic power which results in the wielding of political power and influence...it is rather political power which creates the possibilities of enrichment and which provides the basis for the formation of an economically powerful class, which may in due course become an economically dominant one. The state is here the source of economic power as well as an instrument of it". That is to say, the ultimate interest of the peripheral politicians is to convert the socially created wealth to private hands! Thus, it is no longer 'the greater good for the greater number of people' (as the Utilitarian disciples would suggest), but the greater good for the few oligarchic number of the ruling 'class-state'. To be sure, the interest of such politicians is pinned on some of the key sectors of the economy like the oil sector which is the zone of attraction of the politicians cum transnational corporations to exploit and dominate the peripheral local economy. In collusion with the transnational agents, the tactics of the politicians are very glaring: they exploit the resources of the periphery and share the "booty" with transnational corporations (Chevron, Mobil, Elf etc.), and to cover up their "political shit" they increase oil prices thus pushing the pains of the economic crunch on the rabble, the masses! -This in a systemic way, catapults the entire citizenry into hardship of apocalyptic proportions: high cost of living with escalating consumer price index; indeed, abject poverty! Several increases of oil prices in Nigeria with its concomitant consequences on the populace are a case in point. Ridiculous, and yet pitiable, while the transnational corporations (the foreign economic 'rapist') take their share of the "booty" back home to develop their nations, the peripheral bourgeoisie (the local economic 'rapist': peripheral political class) convert their own share of the "booty" into their hidden private accounts (and most of these accounts are in the banks of the advanced capitalist nations where the public funds are stashed, further helping the economies of the advanced capitalist nations) while the peripheral domestic economy is stifled, underdeveloped, and rendered to absolute impoverishment.

The military does directly what the civilians [the ruling class] does indirectly through the military. -Wilmot (1985).

Normatively, the primary roles of the military as a coercive state apparatus include that of: "1). Defending and protecting the status quo; 2 ). Provision of security for the state, and 3 ). Defending and 
protecting the territorial integrity of the society at large" (Ninalowo, 2004: 93). Remarkably, the first role of the military as adumbrated above rings a bell -"defending and protecting the status quo". A brief exposition of this shall be very constructive for the epistemic raison d'etre of the discourse: that is to say, the military in its "status quo-defending" role serves as a repressive apparatus of the state (the ruling class) against any challenge that might arise from the underclass (the subaltern classes: civil society, irate youths, etc) who may arise as a counter-hegemonic forces to kick its existence or status quo. To be sure, the ruling class, while exploiting the masses, will likely use its coercive apparatus (the military) to protect itself against any position. Thus, 'indirectly', as Wilmot (1985) rightly pointed out above, the ruling class uses the military for its own private interest. As corroboration to the forgoing thought process, Arthur Nwankwo (1989) was very explicit in portraying its vicious scenario in African political landscape in his choice words, "[in Africa] the way the state apparatus is deployed to the elimination of individuals who disagree with government policy deprives most African leaders of the moral rationale for lampooning racist minority regimes in the continent" (p. vi).

Ethically, the military is not to be involved in politics. But often times, there are intermittent military putsch here and there as witnessed in some African countries like Nigeria (circa, 1966 - 1999), also in Ghana (1981, 1979), and in several other peripheral social formations of the Global South nations like South-East Asia and Latin America (e.g. Fidel Castro's Cuba). Usually when the military come into power, they lure the unsuspecting masses with their self-styled epithet that they are "corrective regimes" that have come to salvage the masses and the economy from the ineptitude and corruption of the civilian ruling class. Paradoxically, once they have stepped into power themselves, they become intoxicated by the same economic power (like the regime they have come to "correct") becoming "corruptive regimes" instead; turning into "bourgeoisies in khaki uniforms" while using guns and violent means to repress any counter-hegemonic opposition against their regime -thus doing "directly" what the civilian ruling class do "indirectly" with the military (a la Wilmot, 1985). The corollary is, they refuse to relinquish power but continue to amass wealth to the detriment of the generality of the public, with policies like privatization of the economy which benefits them and the transnational corporations, thus stifling development in the periphery. Typically, Nigerians will not forget in a hurry the despotic and most corrupt military regime of late General Abacha (1993-1998) who looted Nigeria's treasury in billions of dollars and stashed away in several banks of the advanced capitalist nations, Swiss, London, U.S.A, et cetera; with his secret 'Gestapo' or assassins ready to eliminate any one that challenges his shenanigans. Up to the moment, some of his loots are still being repatriated back to Nigeria from the foreign nations piecemeal - e.g. \$200 million USD out of the $\$ 700$ million USD stashed at Swiss bank was repatriated by Swiss in 2006 (SWISS-info December 5 , 2006); on May $4^{\text {th }} 2020$, U.S.A repatriated $\$ 311$ million USD, part of Abacha loot stashed in U.S.A (Premium Times, May $4^{\text {th }}$ 2020), to mention but a few!

However, for a theoretical appreciation of the conceptual nexus between 'vested interests' and the 'contradictions of underdevelopment of the peripheral social formation', a theoretical framework shall here be very helpful - The Concept of Marxian Ideology. To this, we now turn.

\section{Theoretical Framework: The Marxian Ideology}

The ideas of the ruling class are in every epoch the ruling class ideology.- Marx and Engels (1969).

Conceptually, the term ideology denotes a set of ideas which presents only a partial view of reality (Haralambos, 1980). 'Partial', because such ideas are ideas of a particular class, the ruling class -to the detriment of the subject class. To be sure, ideology connotes a set of beliefs and values which express the 'vested interests' of a particular social group. Such vested interests of a particular group serve the benefit of the ruling class while portending alienation, marginalization and exploitation for the subject class (the subaltern individuals, the rabble, poor masses). This will be better appreciated with a contextual analysis of Marxism or the Marxian Ideology. 
Marxism or Marxian Ideology is named after its founder, the German-born philosopher, economist, and sociologist, Karl Marx (1818-83). In line with his theoretic conjectures, to meet man's material needs man enters into social relationship with other men for a social enterprise, for the production of his economic or material needs. This involves forces of production: labor, raw materials, technology, skilled knowledge and capital. To Marx, all historical societies are fraught with immanent contradictions which involve one social group/class exploiting the other social group or class -there is always a conflict of interests since in the 'dialectical materialism' one group gains at the expense of the other. Thus, the crux of the contradiction is between 'forces of production' and 'relations of production'. (The relations of production exude the relationship between the employer and the employee, the propertied-class and the proletariat, the ruling class and the subject class, or the Haves and the Have-nots; and the rights and expectations involved in such relations). Marx maintained that only labor of the workers (the property-less class, the owners of labor) produces the wealth, but these wealth are exploited by the capitalist (the propertied-class, the owners of 'forces of production') for profits while the owners of labor (the workers, the subject class) that produced the wealth are paid mere wages (this inherent contradictions, according to Marx, and the capitalists' passionate interest for pursuit of profits will eventually lead to the downfall of the capitalist system). Marx further maintained that these existing contradictory relations of production between the dialectical classes must surely reproduce itself into political and legal relations, where the dominant social group or the ruling class who own and control forces of production will largely monopolize political power, and will enact laws framed to protect its position and further its vested interests. But as these contradictions are bound to intensify, the subject class will later become aware ('class consciousness') of its subjugated position, and will metamorphous from being 'class-in-itself (state of 'false consciousness') into 'class-for-itself' (a state of awareness where the subject class has recovered from the 'false consciousness' of 'general interest and freedom' sold to it by the ruling class ideology and rationality) and fight by way of revolution for a change. For this, Marxism is regarded as a revolutionary theory and a paradigm for social change. But Marx wasn't alone in this paradigmatic revolutionary way for change, Fanon (1970) shared the same view; in his own words, "the function of a social structure is to set up institutions to serve man's needs. [But] a society that drives its members to desperate solutions in a nonviable society, is a society to be replaced" (p. 63).

Therefore, from the drifts of Marxism, the existence of a dominant class, and the persistence of its class ideology, usually precipitates into another class -the subaltern class, whose own ideas dialectically opposes the ruling class ideology, as the subjugated class (subaltern class, the subject class, the 'have-nots') graduates from being a 'class-in-itself into a 'class-for-itself in form of organized civil society in counter-hegemonic revolutionary activities (civil protests, mass riots, strikes, etc.) to challenge the status quo and bring about change. For no subjugated individual or group who has been under the miasma of dominance and oppression for long, who becomes conscious of the social reality of his alienated social position, will remain an under-class for long but must inevitably seek ways for liberation -and this comes often in form of resistance against the vexing status quo. Hence, in every moment of domination there is usually attached to it, moments of resistance arising from the down-trodden or the alienated class! This thus, explains the immanent contradictions of the vested interests of the ruling class in peripheral social formations. Its antinomies or negative consequences usually reproduce actions and counter-actions that are antistate which may be anti-development or may promote development. We shall like to expound on these antinomies further with the concept of 'Legitimation and its crisis'.

According to Harbermas (1975), legitimation is a mechanism by which the ruling class seeks to gain allegiance and loyalty of a given population in general. That is to say, the attempts of the state to fabricate legitimacy for itself by providing the populace with some welfare facilities (a hoax to sell 'false consciousness' to the people as a responsible government) like employment, insurance benefits, subsidized housing, government assisted mass transit system, etc., so as to subtly repress any opposition that may kick against it from below (i.e. from the under-class) and rather invoke belief ('false consciousness') in the populace that their government is good. However, the kernel of the 
concept of legitimation that should not be forgotten here is that, legitimation is a function of the provision of human-centered development facilities geared towards the amelioration of the human condition by the state. Put differently, the state does not merit legitimacy if it does not provide these welfare facilities for the people.

Incidentally, because these welfare provisions are not elaborate in the periphery as they are in the advanced nations, and the populace tend to suffer in the "midst of plenty" -that is "crisis of legitimation' (a mismatch between 'what is' (the reality on ground) in the State role: lack of welfare for the people; and 'what ought to be' (ideal situation): welfare provisions); it triggers off counterhegemonic activities of the subaltern classes (the civil society, trade unions, irate youths, etc.), antistate systems (e.g. separatist agitations: Niger Delta movements, MASSOB, IPOB, etc.) who tend to counter the dominant class and exit from the state as the state no longer merits its legitimation (Osaghae, 1999). Thus, these crises propensities and socio-political ruptures emanating from overambitious vested interests of the ruling class engender political instability -and political instability is anti-development. Political instability is very rampant in most peripheral social formations, and this underscores the reason for the persistent underdevelopment of the peripheral states (like Nigeria) despite their ceremonial or nominal-flag political independence. By way of a critique, although Marxism predicted the downfall of capitalism due to its immanent contradictions; however, capitalism has continued and still spreading globally. But the relevance of Marxism is its strength in revealing the dialectical interests and contradictions that arise within class cleavages whose antinomies may or may not promote development process or progressive social change. And that is relevant to our present discourse.

Having explored the antinomies of the vested interests of the neo-colonial peripheral elites and its inter-linkages with the underdevelopment of the periphery so far; at this juncture, we shall now explore the vested interests of the Capitalists of the Center and its implications in the peripheral development process as was promised ab initio. To this we now turn.

\section{The Vested Interests of the Capitalists of the Center versus the Contradictions of Underdevelopment in the Periphery.}

Perhaps, closely related to the structural distortions of the peripheral local economies and the contradictions of the vested interests of the peripheral ruling class are the dynamics within the capitalist international division of labor of 'developed nations' and 'underdeveloped or developing nations'. That is, the dynamics of the relationship between the underdeveloped or less developed countries (LDC's peripheral states) and the Center (the advanced Capitalist nations); the relationship is not one of symbiosis where both should benefit on egalitarian lines, but one where the vested interests of the dominant nations lead to the insidious exploitation of the subordinate nations (the periphery) resulting into twin consequences: the development of the Core or the Center (the advanced capitalist nations), and the underdevelopment of the periphery -Gunder (1966) has called this, "development of underdevelopment". For the purpose of epistemic clarity, the 'Dependency perspective' represented by Gunder Frank (1966) shall be very helpful as a mediatory notion to capture these dynamics in what follows.

Prominent in this perspective are Baran (1960), Gunder (1966,1972), Amin (1974) and Wallerstein (1975). According to this school of thought, the capitalist world-economy consists of asymmetrical hierarchical international division of labor. Within this unequal division of labor, the economically and technologically developed nations which constitute the CORE (the Metropolis) have historically exploited the resources of the 'Periphery' (the less developed economies) by expropriating the economic surplus of the latter. This deceit stagnate the economy of the periphery where affluence is produced in the Core, but impoverishment created in the periphery. By way of precision, and helpful insights from the thesis of dependency perspective, the following points typically underscore the various insidious avenues by which the patterns of skewed economic relationship between the Core and the Periphery, invaded by the vested interests of the Core, reproduces contradictions of underdevelopment in the peripheral social formation:

1. Exploitation through repatriation: The transnational corporations (e.g. the Multinational oil 
corporations -Chevron, Mobil, Shell, etc.) of the Core re-invest in the periphery only a fraction of the profits derived from their investments in the peripheral domestic economy, while the bulk of these profits is shipped home or repatriated for the benefit of their own nations (the advanced nations).

2. Elite Complicity: The peripheral capitalists (i.e. the ruling class or the "comprador bourgeoisies" a la Wilmot (1985)) enter into various types of (trade) agreements with the affluent Core (capitalists' nations) to maintain the status quo in the underdeveloped countries because the elites of both countries benefit from the prevailing economic situation -elitist vested interests. This elite collusion or conspiracy may come in form of 'kickbacks', 'over-invoicing' of projects, 'illegal percentage commissions/charges', 'bribery', etc.

3. Structural Distortion: This entails 'economic articulation' at the Center while 'economic disarticulation' at the Periphery (Amin, 1974). That is to say, at the Core, there is structural cohesion of its economy -development in one sector stimulates development in all other sectors (i.e. 'articulated economy'), but at the Periphery, development in one sector does not stimulate development in other sectors (i.e. 'disarticulated economy'). For instance, in Nigeria, at the beginning of the first quarter of 2020, Nigeria was ranked 28th in terms of nations with largest GDP globally (with her GDP of $\$ 446.5$ billion USD) yet has the largest number of people living in abject poverty (Premium Times January 19th, 2020) with poverty rate as high as $40 \%$ (NBS, 2020), unemployment rate as high as $23 \%$ (Premium Times January 19th, 2020), and with a low human development index of 0.534 (UNDP, 2020) -signifying that its economic gains in high GDP did not stimulate development in other sectors. The growth in the economic infrastructure did not stimulate growth in other superstructures of the Nigerian society. The reason for such disarticulation in the economy of the periphery is that, the proceeds of this particular developed sector only benefits the capitalists of the periphery and their advanced capitalist masters (the Core), where the peripheral capitalists (the ruling class) instead of channeling the economic proceeds judiciously to stimulate development in other sectors rather enriched only themselves and their capitalist masters of the advanced nations (through their secret arrangement with the multinational corporations of the advanced nations), while development in the periphery is stifled. Corroborating this, Arthur Nwankwo (1989: 137) emphatically observed that, "Nigerian economy [disarticulated economy] is a neo-colonialist capitalist economy, sustained by the ethics of materialistic egoism...Its essential dynamics are lodged in yawning class disparities and in great distances between social groups in their respective proximities to the national wealth...Beyond that, this economy is externally-oriented, with clandestine foreign cartels controlling internal productive forces...[This] disarticulates the...linkages between the economy's accelerator and multiplier potentialities...in such a way that...the absence of development or poverty of growth exacerbates...inequalities...proliferating systemic crises [that reproduce] political instability".

4. Discouragement of industrialization: That is, the ability of the rich capitalist nations to disrupt efforts at industrialization by peripheral countries by 'dumping' cheap products ("Tokunbos" already used materials from advanced nations grabbed for use by the peripheral nations) in the capitalist-controlled markets of the periphery. This discourages initiatives and idea generation in the periphery to come up with innovations that can boost industrialization which is sine qua non for development. Akin to lack of impetus for industrialization, is the continued borrowing (by the peripheral nations) or attachment to the credit facilities of the advanced capitalist nations IMF systems, with its exorbitant interest rates that keep the peripheral nations perpetually indebted to them. The advanced capitalist nations with their IMF systems are ever ready to give out the credit facilities (and often lures the peripheral nations to request for it), because the Capitalist of the Center (with their usual 'bourgeoisie rationality') understands that the devastating burden of interest rates attached to the loans will weaken 'savings culture' -which is a desideratum (required but lacking) for industrialization -in the periphery. Often times, in the usual 'bourgeoisie rationality' of the advanced capitalist nations' IMF systems, they would forgive some of the 'bad debts' of the peripheral nations. But this is only a ruse or a hoax to make the 
peripheral nations ask for more loans and be perpetually indebted to them. As it were, where the peripheral nations think that IMF is lenient with their 'debt forgiveness', and hence continue the 'credit relationship', they have only fallen into the trap of advanced capitalist nations and remain forever indebted, and forever lacking the 'savings' for industrialization.

5. Aids and Grants: That is, the concessions of Aids or Grants by the advanced capitalist nations to the peripheral nations which keep them indebted to the capitalist Centre and make them remain externally dependent on them. Paradoxically, as Olurode (2006: 3) observed, "more resources flow out of the Periphery (e.g. Africa and Asia) than what comes in as aids and foreign direct investment (FDI). Even the so called 'Aid grants' is not for free, there are subtle strings attached to it -the hidden mindset of a capitalist neo-liberal (free market) economy is usually "Aids for Trades" (Knuttson, 2009): the aids granted to the peripheral nations is a 'lobbying tool' (a 'bourgeoisie rationality') by the advanced capitalist nations to pave way for trade pacts with peripheral nations to maintain their capitalist stranglehold and exploitation in the periphery. Again, the international financial institution, especially the IMF demands as preconditions for granting loans to recipient countries, the adoption of economic policies [like privatization of public utilities and structural adjustment programs] that are favorable to private corporations, especially the transnational ones (Ninalowo, 2004). The consequences of these IMF-oriented measures are to promote foreign direct investment to enhance the profits of transnational corporations (MNC's) while stifling industrialization of peripheral economies. And this has concomitant effects: unemployment, under-employment, low standard of living, environmental pollutions, cut-backs in social amenities needed for the amelioration of human condition in the peripheral countries -which finally culminates into total dependence on the advanced capitalist nations (neo-colonialism!).

\section{Rounding Up/Conclusion}

$\mathrm{Ab}$ initio, the paper informed that there exist vested interests not only at the global levels between developed and underdeveloped nations of the world, but equally so among the neo-colonial elites in the peripheral local economy. It is quite evident from the foregoing analyses that the vested interests emanating from both local and international structural economic distortions and inequalities mutually reproduce each other to such a degree as to sharpen immanent contradictions of the underdevelopment of the peripheral social formations. To that the paper uncovered some findings. From the findings, thematic lessons can be drawn as the recurrent motif for the persistent underdevelopment of the peripheral nations impinged on vested interests. These include 1). The ruling class of the peripheral nations, especially in Africa (typically, Nigeria), has the culture of diverting national wealth for own personal interests. 2). Every moment of domination usually precipitate moments of resistance by the subjugated class, hence revolutions and instability are endemic in any polity fraught with vested interests of the dominant class and this is ant-development. 3). It is hardly impossible for the advanced capitalist nations to exploit the economies of the peripheral nations without the complicity of the peripheral ruling class. 4). The peripheral nations have remained underdeveloped due to the selfish interests of both the peripheral ruling class and the advanced capitalist nations. Therefore the paper concludes that, the real path to genuine development does not reside in the global set-up of economic relations between the advanced capitalist nations and the developing economies; and that no nation would move forward whose leaders are influenced by vested class interests rather than by the popular interest of the generality of the citizenry.

The paper therefore recommends: a plausible alternative will be for the peripheral social formations to pursue serious independent policies of social justice along egalitarian lines as well as economic and political self-reliance -like state incentives and/or support for local industrialists, and passionate and selfless focus on integrating and strengthening the domestic productive base to achieve a self-reliant articulated economy. Of course, while one is not advocating for a system of 'autarchy' or absolute separation from the rest of the world, rather this is an advocacy for an international network whereby the interest of the subordinate nations (the periphery) are not subservient to those of the dominant nations to 
the detriment of the human condition of the masses in the periphery. Additionally, there should be strict checks and balances among the ruling class of the periphery so that the excesses of one faction (the overambitious executives) could be tamed. Furthermore, there is need for commitment to democratic ethos or permissiveness and popular-empowerment socio-economically, politically, and legally -provisions of basic facilities for the amelioration of the worsening socioeconomic conditions in the periphery; allowing popular opinions or peoples' participation in the political decisions of the state as well as respect and recognition of their fundamental human rights.

\section{References}

Adepolu, A. (2001). Perspective on Population Education in Nigeria. Lagos: Concepts Publishers Ltd.

Amin, S. (1974). 'Dependency Perspective'. In, K.S Sanderson (1995) (Ed.).

Macro Sociology: Introduction to Human Societies. New York: Harper Collins College Publishers.

Arthur, A.N. (1989). Before I Die -Obasanjo and Arthur Nwankwo Correspondence on the One-Party State. Enugu: Fourth Dimension Publishing Co. Ltd.

Baran, P. (1960). The Political Economy of Growth. London.

Fanon, F. (1963). The Wretched of the Earth. New York: Grove Publishers.

Fanon, F. (1970). Towards African Revolution. Penguin.

Financial Standard (January 29, 2007). 'Economic and Financial Indicators'. 8 (62), 1; 49.

Gunder, F. (1966). "The Development of Underdevelopment". Monthly Review. 18, 4; 17-31.

Gunder, F. (1972). Lumpenbourgeoisie and Lumpendevelopment: Dependency, Class, and Politics in Latin America. New York: Monthly Review.

Habermas, J. (1975). Legitimation Crisis. Boston: Beacon Publishers.

Haralambos, M. (1980). Sociology: Themes and Perspectives. London: University Tutorial Press.

Hume, D. (1948). A Treatise of Human Nature. New York: Macmillan.

Knuttson, B. (2009). 'The Intellectual History of Development: Towards a Widening Potential Repertoire'. University of Gottenburg. Perspective. No. 13. April.

Mark, K and Engels, F. (1969). 'Manifesto of the Communist Party (Selected Works)'.Moscow: International.

Miliband, R. (1977). Marxism and Politics. London: Oxford University Press.

Ninalowo, A. (2004). Essays on the State and Civil Society. Lagos: First Academic Publishers.

NBS (2003). 'Poverty Profile for Nigeria -2003 edited paper for Nigeria'. National Bureau of Statistics. www.nigerianstat.gov.ng

NBS (2020). Poverty and Inequality in Nigeria 2019: Executive Summary. www.nigrianstat.gov.ng

NBS (2020). Unemployment rate in Nigeria, National Bureau of Statistics. www.nigerianstat.gov.ng

Olurode, C. (2006). "Diminishing Frontiers of Human Services in the Contemporary World"-Readings in Social Work. Lagos: Department of Sociology Publication (Unilag).

Osaghae, E.E. (1999). ‘Exiting From the State in Nigeria’. African Journal of Political Science. (4), No. 1.

Premium Times (January 19th, 2020). "ANALYSIS: Why Nigeria's Vision 20: 2020 was bound to fail". www.premiumtimes.ng.com/news/top-news/37330-analysis-/

Premium Times (May 4th, 2020). "How Buhari's government will use \$311m USD recovered from Abacha loot presidency". www.premiumtimes.com/391500.

Punch (June 3, 2020). "Revised Budget: FG gives National Assembly N27 Billion for Renovation cuts health, UBE votes".

www.punchng.com/revisedbudget-fg-gives-nat-ass-n27b-for-renovation-cuts-health-/SWISS-info (December 5, 2006). 'Swiss responds to Abacha funds allegation'. Swiss Broadcasting Corporation. www.swissinfo.ch/eng/swiss-responds-to-abacha-funds/

UNDP (1991). Human Development Report. New York: Oxford University Press.

UNDP (2020). '2019 Human Development Index ranking of 189 countries'. Human Development Report office. www.undp.org

Vanguard (February 17th, 2018). "Snakes allegedly swallow N36 million from JAMB office vault, Nigerians react".

www.vanguardngr.com/2018/o2-snake-allegedly-swallow-n36m/

Vanguard (February 21, 2018). "Shocker! Monkeys swallowed N7om belonging to Northern Senators Forum". www.vanguardngr.com/2018/o2/monkey-swallowed-n7om/

Wallerstein, E. (1979). The Capitalist World Economy. London: Cambridge University Press. 
William, D. G. (1982). 'Nigerian Elite Consolidation and African Elite Theories: Towards an Explanation of African Liberal Democracy 1. Paper presented to the 12th Annual Conference of the Canadian Association of African Studies, Toronto, 10-14 May, 1982.

Wilmot, P. (1985). Sociology: A New Introduction. London: Collins International Textbooks.

World Bank (2020). Advancing Social Protection in a Dynamic Nigeria. The World

Bank Group. www.worldbank.org 